\title{
Genetic parameters and genetic and phenotypic trends of performance traits of equines from the Brazilian Army
}

\author{
Mariana de Almeida Dornelles ${ }^{1}$, Ronyere Olegário de Araújo $^{2}$, Dionéia Magda Everling ${ }^{1}$, \\ Tomás Weber ${ }^{1}$, Jader Silva Lopes ${ }^{3}$, Paulo Santana Pacheco ${ }^{4}$, Fernanda Cristina Breda ${ }^{4}$, \\ Paulo Roberto Nogara Rorato ${ }^{4}$
}

\footnotetext{
1 Programa de Pós-Graduação em Zootecnia/UFSM, 97105-900, Santa Maria, RS, Brasil

2 Programa de Pós-Graduação em Ciências Animais/FAV-UnB, 70910-900, Brasília, DF, Brasil.

${ }^{3}$ CIEx Agropecuário - Sadia S/A - Concórdia, SC, Brasil.

${ }^{4}$ Departamento de Zootecnia/UFSM, 97105-900, Santa Maria, RS, Brasil.
}

\begin{abstract}
The objective of this research was to compare the magnitude of genetic parameters (coefficients of heritability and genetic correlation) as estimated by the Restricted Maximum Likelihood (REML) method and Bayesian Inference, and to estimate the genetic and phenotypic trends to the traits height at the withers (HW24) and weight at 24 months of age (W24). The average heritability estimated by Bayesian Inference to HW24 was 0.47, and it was lower than that obtained by REML bi-trait analysis (0.52); however, the value estimated to W24 (0.39) was higher than that obtained by REML bi-trait analysis (0.38). The genetic correlation estimate between W24 and HW24 traits obtained by the REML method (0.66) was lower than that obtained by the Bayesian Inference Method (0.72). From the regression of the average additive genetic merit in the year of birth of the animals, it was found that the averaged genetic values of the animals for HW24 showed a genetic trend near zero $(-0.0008 \mathrm{~cm} / \mathrm{year})$, and the averaged genetic values for W24 showed a negative trend of $-0.38 \mathrm{~kg} / \mathrm{year}$. The values to the direct heritability estimated for HW24 and W24 suggest that the direct selection for these traits can provide genetic gain in this population. The genetic correlation between the traits, high and positive, suggests that the selection for HW24 should promote increase in W24 at this age. The genetic trends obtained for the traits studied, near zero, indicate that the selection performed produced a slight reduction of the weight of the animals at 24 months of age; however, it did not promote increase in height at the wither at this same age, in this population.
\end{abstract}

Key Words: genetic correlation, genetic progress, variance components

\section{Introduction}

The equines used in the Brazilian Army today are mostly used for mounted patrols and guard, participation in military ceremonial parades, honor guard and escorts of authorities, military education in schools of officers and soldiers, besides sports activities such as jumping, polo, and dressage, and for these purposes, adequacy of some traits by selection is necessary.

Estimates of heritability are important tools in genetic improvement programs because they allow estimating how much of the phenotypic variation in the trait is due to additive genetic effects, as well as the expected genetic gains and the genetic values of individuals of a population. However, for this purpose it is necessary to select an appropriate statistical method that best reflects the biological behavior of the traits studied. In this context, several procedures for variance components estimation have been proposed for application in animal breeding (Faria et al., 2007).
According to Gianola et al. (1994), if frequentist methods, such as the Restricted Maximum Likelihood (REML) are used, only punctual genetic variance estimates are obtained. The Bayesian approach, in addition to punctual estimates, allows determining intervals of credibility for a posteriori distribution of the variance component, without approximations or use of normality assumptions, and thus is more advantageous than the frequentist procedures (Falcão et al., 2009).

The selection usually practiced in equine species is based on subjective criteria and on the experience of the breeders, which indicates the existence of evidences that important characteristics of equine species have been altered over the generations (Bergmann et al. 1997), such as the decreasing size of the animal as a whole in ponies or the increasing height in sports horses. One way to scientifically examine the results of a selection program would be by means of the genetic trend of the population regarding the trait of concern. In this study, the genetic progress over time was examined by using the mean regression of the 
genetic merits of all animals of the population as a function of the birth year (Klemetsdal, 1990).

The objective of this study was to compare the magnitude of the genetic parameters (coefficients of heritability and genetic correlation) estimated by the Restricted Maximum Likelihood method and by Bayesian Inference, and estimate the genetic and phenotypic trends for the traits of height at the withers and weight of 24-month-old equines of the Brazilian Army.

\section{Material and Methods}

The database used for this experiment was supplied by Coudelaria de Rincão (or Rincão Stud Farm), a military organization that produces horses for the Brazilian Army, located in the municipality of São Borja, west of Rio Grande do Sul, Brazil ( $28^{\circ} 44^{\prime} 29^{\prime \prime S}$ and 55 $\left.5^{\circ} 4^{\prime} 48^{\prime \prime} \mathrm{W}\right)$. The original database was constituted of records for the characteristics of height at the withers and weight at 24 months of age of 1,475 animals of the breeds Brazilian Showjumper, Breton, Hanoverian, English Thoroughbred, and a group of animals of no defined breed, born in between 1996 and 2007, which constitute the current population. Data were assessed for consistency of the records, and seven years of records of births were disregarded in this process for not having information on breed and gender. To organize the file of study, two birth seasons were created: the first (season 1) comprised the period from March to August, with 30 animals, and the second (season 2) from September to February, with 489 animals, as a consequence of the reproductive physiology of the mare, which is photoperiod positive.

To verify the effects of the gender, coat, genetic group, birth year, and season variables for the traits studied, an analysis of variance was performed, and those with statistically significant effect were included in the contemporary groups, which consisted of the animals of the same genetic group and same birth year and season. Information with less than three animals per contemporary groups was discarded, so the genetic groups of the Breton, Hanoverian, and English Thoroughbred breeds were deleted from the database.

In the study file, records of height at the withers and weight measured in 51924-month-old animals of the Brazilian Showjumper and no defined breeds, born from 251 mares and 39 stallions (16 Brazilian Showjumper and 23 animals of no defined breed) in the period of 2003 to 2007, forming a relative matrix of 809 animals, remained.

Estimation of the variance components required to estimate the genetic parameters and predict the genetic values of the animals was performed by the Derivative-Free
Restricted Maximum Likelihood method (REML) and Bayesian Inference.

The REML method was used with the computer program MTDFREML (Multi Traits Derivative Free Restricted Maximum Likelihood) described by Boldman et al. (2001), and the criterion for convergence assumed was when the logarithm of the likelihood ratio was lower than $1 \times 10^{-9}$. The animal model used to obtain genetic parameters, in a bitraits analysis, described in matrix form, was the following: $\mathrm{Y}=\mathrm{X} \beta+\mathrm{Z}_{1} \mathrm{a}+\mathrm{e}$, where $\mathrm{Y}=$ vector of the observations of each trait - Weight and Height at the withers; $X$ = incidence matrix associated with the fixed effect of the CG; $\beta=$ vector of solution for the fixed effect; $Z_{1}=$ incidence matrix associated with the direct additive genetic effect of each animal; a = vector of solutions for the random additive direct genetic effects; e = vector of wastes.

The Bayesian method was the second method used to estimate the variance components, and for this purpose, the computer software GIBBS2F90, developed by Misztal (2007), under the animal model described above, in a bitraits analysis was used. The authors generated chains of 600,000 Gibb iterations with discard of the first 300 iterations (burn-in), in order to minimize the effects of the first values. To ensure the independence of the samples, a sample interval every 200th iteration was considered. After processing the analyses in GIBBS2F90, estimates of heritability, genetic correlation, and the credibility region were obtained using the software SAS (Statistical Analysis System, version 9.2).

The burn-in period (number of iterations that should be thrown away), the chain length and the minimum distance between one iteration and another were determined by the method of Raftery \& Lewis (1992). Convergence was tested by using the criteria proposed by Geweke (1992) and Heidelberger \& Welch (1983). Software R (version 2.12.0), with some routines of the Bayesian Output Analysis (BOA) package, was used to calculate the statistics of Raftery \& Lewis (1992), Geweke (1992) and Heidelberger \& Welch (1983). The serial correlation was checked by the software GIBANAL (Van Kaam, 1998).

The genetic trend for the traits under study was calculated by the mean regression of the genetic values, weighted by the number of observations, on the year of birth. The procedure used was PROC REG, of the software SAS (Statistical Analysis System version 9.2), with the following mathematical model: $\mathrm{Y}_{\mathrm{i}}=\mathrm{b}_{\mathrm{o}}+\mathrm{b}_{1} \mathrm{x}_{\mathrm{i}}$, where $\mathrm{Y}_{\mathrm{i}}=$ genetic value for the traits examined (height at the withers and weight) and ith year of birth; $b_{0}=$ intercept; $b_{1}=$ coefficient angle of the line; $\mathrm{x}_{\mathrm{i}}=\mathrm{i}$ th year of birth. To estimate the phenotypic trend, the same procedure was used, with 
the means of the phenotypic values of height at the withers and weight, weighted by the number of observations, in the year of birth.

\section{Results and Discussion}

The analysis of variance (Table 1) showed that the effect of the gender of the animal on weight and height at the withers at 24 months of age was not significant, unlike what was found in the literature for English Thoroughbred (Thompson \& Smith, 1994) and Pantaneiro horses (Santos et al., 2007), in which males usually showed lower growth rates than females. However, Green (1969), when evaluating the growth of English Thoroughbred foals from birth through 12 months of age, did not find difference between the genders regarding the height measure at the wither, which may be a trait of the English Thoroughbred, according to the author, and Campos et al. (2007) also found no significant difference between the gender of all horses of the Brazilian Army.

The birth season showed significant effect on the two traits examined; according to Mota et al. (2010) it is possible that animals born in late winter are from mares that just entered the reproduction period and conceived at the beginning of the mating season and, therefore, were in good nutritional and health conditions, providing better prenatal and postnatal environments for their offspring.

Although inbreeding has been widely used in the formation of most equine breeds in order to establish some desirable traits and/or influences of some ancestors in progenies (Wagoner, 1978 apud Abrahão et al., 2002), in this population, of the total of 1,475, only 13 were inbred, with an average inbreeding coefficient of $0.125 \%$. However, this figure cannot reflect the real inbreeding levels of the herd under study, since the genealogy of most of the animals studied was limited to the grandparents. On the other hand, this value can be justified by the use of breederassisted mating and introduction of stallions of other populations as well as the semen from different breeds of the herd. These procedures ${ }^{1}$ were adopted in order to obtain animals that would fit the physical trait desired by the Army, with height above $1.60 \mathrm{~m}$.

The heritability for the weight at 24 months (Table 2), estimated by the REML method was 0.38 , i.e., lower than that found for a population comprised by Quarter horse, Mangalarga, and Arabian breeds animals (Faria et al., 2004) and for Brazilian Showjumper and animals of no defined breed (Campos et al., 2007).

The coefficient of heritability estimated for the height at the withers, 0.52 , obtained by the REML method (Table 1) was similar to those found for the Mangalarga Marchador and Mangalarga breeds (Zamborlini et al., 1996 and Mota et al., 2006, respectively), and nearly $27 \%$ lower than that estimated for the Campolina breed (Santos, 2006). Such differences in heritability between the breeds/herds can be explained by different environmental effects on each population, depending on the animals breeding region, because the smaller the adverse effects of the environment on the traits studied the greater the additive effect of the genes.

The magnitude of the heritabilities estimated for the traits studied in this population suggest that it is possible to obtain genetic gains by mass selection.

The average heritability estimated by Bayesian Inference to HW24 was 0.47 , and it was lower than that obtained by REML bi-trait analysis (0.52); however the value estimated to W24 (0.39) was higher than that obtained by REML bi-trait analysis (0.38). These results corroborated those reported by Magnabosco et al. (2003), who found higher estimates produced by the Bayesian Method than those

Table 1 - Summary of the variance analysis of height at the withers and weight traits at 24 months of age

\begin{tabular}{lccccc}
\hline Traits & Gender & Coat & Genetic group & Birth year & Birth season \\
\hline Height at withers & 0.5185 & 0.0779 & $<0.0001$ & $<0.0001$ & 0.0140 \\
Weight & 0.0011 & 0.7476 & $<0.0001$ & $<0.0001$ & $<0.0001$ \\
\hline
\end{tabular}

Table 2 - Estimates of co(variance) components and coefficient of heritability of height at the withers and weight traits at 24 months of age, by the REML method

\begin{tabular}{lcccc}
\hline Traits & $\sigma_{\mathrm{a}}^{2}$ & $\sigma_{\mathrm{e}}^{2}$ & $\sigma_{\mathrm{p}}^{2}$ & $\mathrm{~h}^{2} \pm \mathrm{SE}$ \\
\hline Height at the withers & 0.00097 & 0.00091 & 0.00188 & $0.52 \pm 0.192$ \\
Weight & 600.69 & 968.97 & 1569.66 & $0.38 \pm 0.183$ \\
\hline
\end{tabular}

$\sigma_{\mathrm{a}}^{2}$ - additive genetic variance; $\sigma_{\mathrm{e}}^{2}$ - environmental; $\sigma_{\mathrm{p}}^{2}$ - phenotypic; $\mathrm{h}^{2}$ - heritability; SE - standard error.

${ }^{1}$ Rodrigues, Personal communication, November 5, 2010, Brazilian Army, Rio Grande do Sul, Brazil. 
obtained by the REML method in bi-trait analyses, for the Nellore breed; Lôbo et al. (1997), for the same breed, found higher values for average heritability by the Bayesian method than the punctual estimation produced by the REML method. The heritability estimates obtained by Prado \& Mota (2008) regarding the height at the withers trait for Mangalarga horses (0.63) was higher than that found in this study.

The a posteriori mean of the genetic correlation (Table 3 ) between the weight and the height at the withers at 24 months of age was positive and with high magnitude (0.66). Such estimate indicates that the selection to increase the height at the withers in the long run should lead to increased weight. This also indicates that most of the additive genes acting in the expression of these traits are common.

The estimated genetic correlation between the traits of weight and height at the wither was 0.72 by the Bayesian method and 0.66 by the REML method, indicating that the selection for weight reduction will provide correlated response at the height at the wither, reducing it, contrarily to the objective of the selection that aims to increase it. Thus, to minimize this problem, at the moment of selection, among the stallions with greater height, low-weight ones should be chosen. The estimate obtained by the REML method is higher than that reported by Faria et al. (2004) for Quarter horse, Mangalarga, and Arabian foals (0.37) and by Campos et al. (2007), for the Brazilian Equestrian (0.49), and for the animals with no defined breed (0.55).

The a posteriori distribution is the most complete description of all information available on the parameter; in this case, the heritability (Winter, 2005). The asymmetry with predominance of high values can be seen by a posteriori distributions of the heritability estimates (Figure 1).

The a posteriori distributions of heritability show that the trait height at the withers presented more homogeneous values regarding weight, consistent with the coefficients of variation of the heritability figures, $24.42 \%$ for height and $31.62 \%$ for weight.

From the regression analyses of the additive genetic merit on the year of birth (Figure 2), it is possible to see that the average of the genetic values of the animals regarding height at the withers at 24 months showed a slight downward trend over the years, with nearly nil genetic trends. The average genetic values of the animals regarding weight at 24 months fluctuated throughout the years and presented negative genetic trend of $-0.14 \mathrm{~kg} /$ year. The Coudelaria do

Table 3 - Descriptive analysis of the variance components of height at the withers and weight at 24 months of age obtained by Bayesian Inference

\begin{tabular}{|c|c|c|c|c|c|c|c|c|}
\hline \multirow[t]{2}{*}{+2} & \multirow[t]{2}{*}{ Serial correlation } & \multicolumn{7}{|c|}{ Heritability } \\
\hline & & $\mathrm{Me}$ & Mo & Med. & Min. & Max. & & CR \\
\hline Hithers & 0.046 & 0.4786 & 0.4738 & 0.4769 & 0.106 & 0.808 & 0.2942 & to 0.7785 \\
\hline Weight & 0.141 & 0.3914 & 0.3372 & 0.3845 & 0.057 & 0.810 & 0.1895 & to 0.6636 \\
\hline \multicolumn{9}{|c|}{$\begin{array}{c}\text { Correlation } \\
\text { Med. }\end{array}$} \\
\hline $\mathrm{HW} \times \mathrm{W}$ & 0.087 & 0.7337 & 0.7986 & 0.7571 & -0.047 & 0.953 & 0.4589 & to 0.9133 \\
\hline
\end{tabular}

CR - credibility region (95\%); Me - Mean; Mo - Mode; Med. - Medium; Min. - minimum; Max.- maximum.
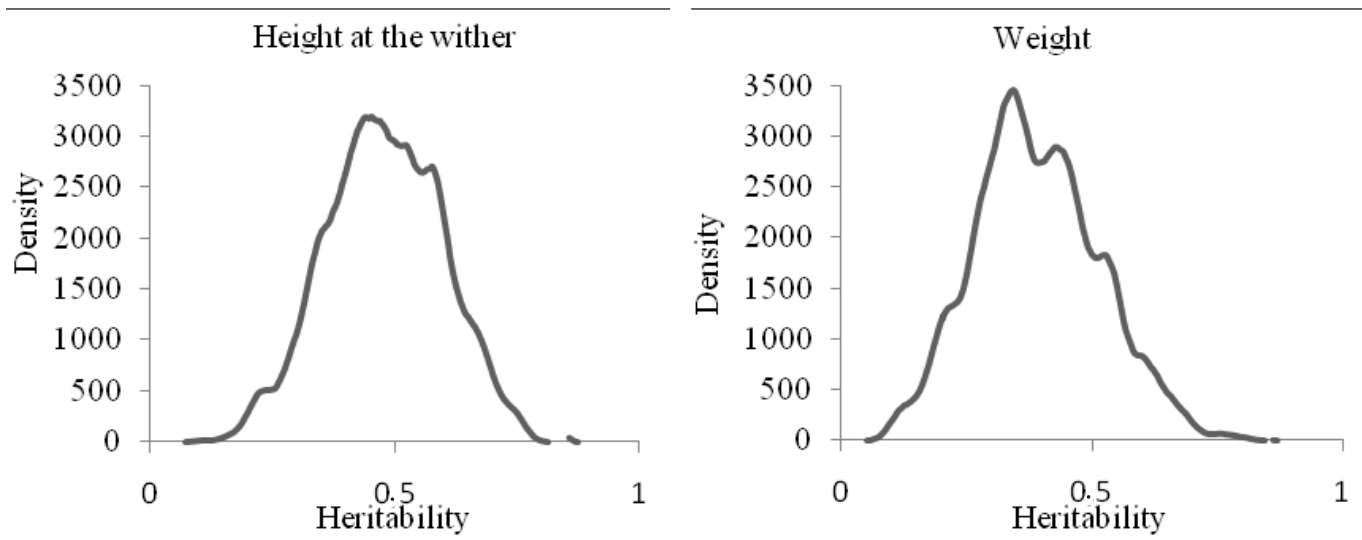

Figure 1 - A posteriori density distribution for heritability estimation of the height at the wither and weight at 24 months of age. 
Rincão selection purpose is to obtain taller and lighter animals with more athletic size. Thus, one of the criteria used to reduce weight was the decreased utilization of larger Hanoverian horses, which are the basis of formation of Brazilian Showjumper and animals of no defined breed. In the past, smaller females were used in this population for breeding, and today, taller ones are used (1.61 m), and the same procedure ${ }^{2}$ was adopted for stallions, which, in the past, had an average height of $1.63 \mathrm{~m}$, which today is $1.69 \mathrm{~m}$. However, the period of time studied (2003 to 2007) was not sufficient to promote increase in the stature of the population.

The literature available on the genetic tendency of the traits observed in equines is scarce. Costa et al. (2001), for Brazilian pony breeds, reported estimates of genetic trend favorable to the reduction of height at the withers, a decrease of $0.075 \mathrm{~cm}$ for each year of recordings; regarding the hip, there was a slight reduction, $0.023 \mathrm{~cm}$ in the 25 years of recordings, showing that the criteria utilized for selection are promoting genetic progress in reducing such traits, since the more valued animals in the market are the smaller ones.

The phenotypic trend in the height at the withers at 24 months of age showed a slight increase of $2 \mathrm{~mm} / \mathrm{year}$ (Figure 3), despite the genetic trend to be nearly nil, as a consequence of no expression of the actual genetic potential of the animals. Regarding weight at 24 months, the phenotypic trend was positive ( $5.06 \mathrm{~kg} /$ year), disagreeing with the results of the genetic trend, which suggests that the selection of the animals would reflect weight decrease, though insignificant. Such weight increase estimated by the phenotypic trend can be explained by a higher nutritional attention given to the animals in this growing stage, providing their maintenance and growth needs, and thus enabling animals to have more weight at this age over the years. On the other hand, Costa et al. (1998), studying Brazilian breed ponies, observed a favorable phenotypic trend, with reduction of almost all linear measures over the years.
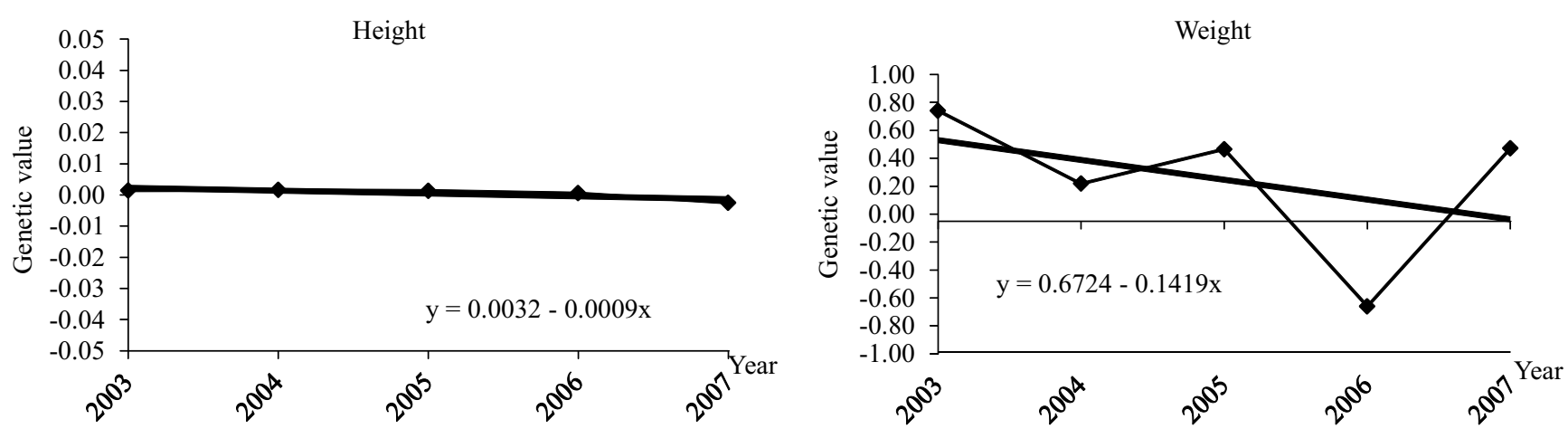

Figure 2 - Genetic trends relating to the height at the withers and weight at 24 months of age of the Brazilian Army horses.
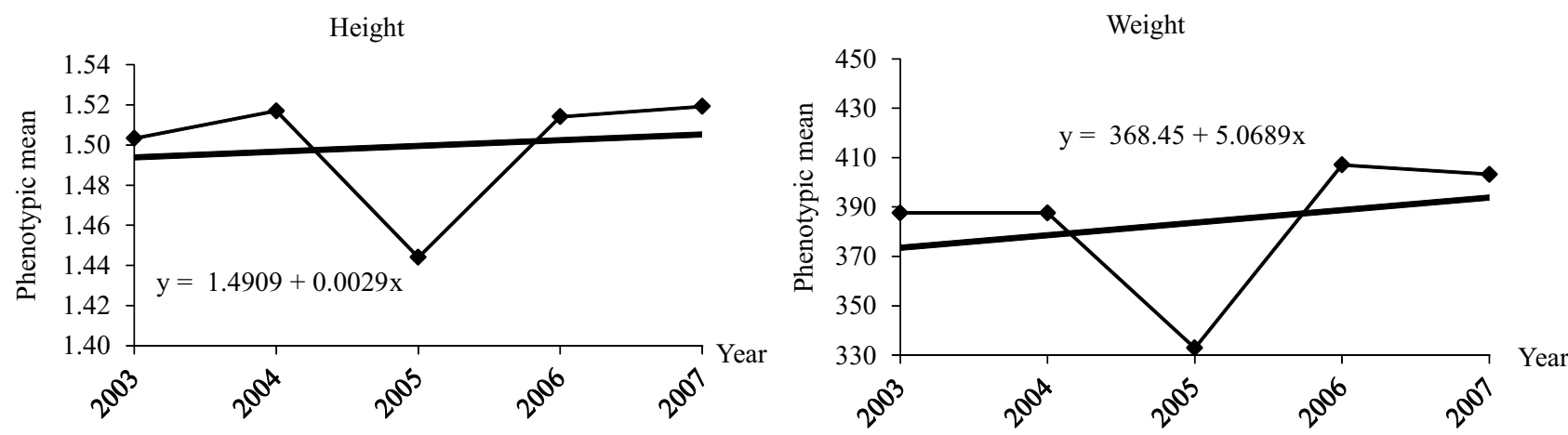

Figure 3 - Phenotypic trends of the height at the withers and weight at 24 months of age of the Brazilian Army equines, according to the year of registration of the animals.

${ }^{2}$ Rodrigues, Personal communication, November 5, 2010, Brazilian Army, Rio Grande do Sul, Brazil. 


\section{Conclusions}

The values of the genetic parameters obtained by the Restricted Method of Maximum Likelihood were lower than those estimated by the Bayesian approach. Advantages were found with the Bayesian method because it enabled punctual estimations and credibility region of the parameters, besides a more appropriate exploration of the data framework. The estimated coefficients of heritability suggest that the phenotypic selection can allow for genetic gains and, therefore, it can be used in this population to increase the height at the withers at 24 months of age and also to reduce the weight of the animals at this age; however, the high and positive genetic correlation between them indicate that special care must be taken in the selection procedures to increase the height without increasing too much the weight at 24 months of age. The genetic trends obtained for the traits studied, near zero, show that the selection has promoted a slight reduction in the weight of the animals at 24 months; however, it did not promote increase in the height at the withers at the same age in this population.

\section{Acknowledgements}

The authors thank the Coudelaria de Rincão (Brazilian Army) for the permission of access to the data used in this research and Conselho Nacional de Desenvolvimento Científico e Tecnológico for the financial support.

\section{References}

ABRAHÃO, A.R.; MOTA, M.D.S.; OLIVEIRA, H.N. et al. Endogamia em éguas da raça Puro-Sangue Inglês. In: SIMPÓSIO NACIONAL DE MELHORAMENTO ANIMAL, 4., 2002, Campo Grande. Anais... Campo Grande, 2002. p.219-221.

BERGMANN, J.A.G.; COSTA, M.D.; MOURÃO, G.B. Formação e estrutura genética da raça pônei Brasileira. Arquivo Brasileiro de Medicina Veterinária e Zootecnia, v.49, p.251-259, 1997.

BOLDMAN, K.G.; KREISE, L.A.; VAN VLECK, L.D. et al. A manual for use of MTDFREML. A set of program to obtain estimates of variances and covariances (DRAFT). Lincoln: Agricultural Research Service, 2001. 120p.

CAMPOS, V.A.L.; MCMANUS, C.; FUCK, B.H. et al. Influência de fatores genéticos e ambientais sobre as características produtivas no rebanho equino do Exército Brasileiro. Revista Brasileira de Zootecnia, v.36, n.1, p.23-31, 2007.

COSTA, M.D. Estudo genético quantitativo das medidas lineares do pônei da raça brasileira. 1997. Dissertação (Mestrado em Zootecnia) - Escola de Veterinária/Universidade Federal de Minas Gerais, Belo Horizonte.

COSTA, M.D.; BERGMANN, J.A.G.; PEREIRA, C.S. et al. Tendências genéticas de medidas lineares de pôneis da raça Brasileira. Arquivo Brasileiro de Medicina Veterinária e Zootecnia, v.53, n.2, p.1-11, 2001.
FALCÃO, A.J.S.; MARTINS, E.N.; COSTA, C.N. et al. Efeitos do número de animais na matriz de parentesco sobre as estimativas de componentes de variância para produção de leite usando os métodos de Máxima Verossimilhança Restrita e Bayesiano. Revista Brasileira de Zootecnia, v.38, n.8, p.1478-1487, 2009.

FARIA, C.U.; MAGNABOSCO, C.U.; REYES, A.L. et al. Inferência Bayesiana e sua aplicação na avaliação genética de bovinos da raça Nelore: revisão bibliográfica. Ciência Animal Brasileira, v.8, n.1, p.75-86, 2007.

FARIA, R.; SILVA, M.A.E.; BUENO, R.S. et al. Avaliação genética e fenotípica de características de conformação em potros de três raças equinas. Revista Ceres, v.51, n.295, p.333-344, 2004.

GEWEKE, J. Evaluating the accuracy of sampling-based approaches to the calculation of posterior moments. In: BERNARDO, J.M.; BERGER, J.O.; DAWID, A.P. et al. (Eds.) Bayesian statistics New York: Oxford University, 1992. p.625-631.

GIANOLA, D.; RODRIGUEZ-ZAS, S.; SHOOK, G.E. The Gibbs sampler in the animal model: a primer. In: FOULLEY, J. L.; MOLENAT, H. (Eds.). Séminaire Modele Animal. La Colle sur Loup, France: INRA Departament de Genetique Animale, 1994. p.47-56.

GREEN, D.A. Study of growth rate in thoroughbred foals. British Veterinary Journal, v125, p.539-545, 1969.

HEIDELBERGER, P.; WELCH, P.D. Simulation run length control in the presence of an initial transient. Operations Research, v.31, p.1109-1144, 1983.

HINTZ, H.F.; HINTZ, R.L.; VAN VLECK, L.D. Growth rate of thoroughbreds: effect of age of dam, year and month of birth, and sex of foal. Journal of Animal Science, v.48, p.480-487, 1979.

KLEMETSDAL, G. Breeding for performance in horse - A review. In: WORLD CONGRESS ON GENETICS APPLIED TO LIVESTOCK PRODUCTION, 4., 1990, Edinburg. Proceedings... Edinburg: 1990. p.184-193.

LÔBO, R.B.; OLIVEIRA, H.N.; BEZERRA, L.A.F. et al. Estimativa de componentes de (co)variância e herdabilidade para o peso aos 120 dias de idade na raça Nelore usando estatística bayesiana. In: REUNIÃO ANUAL DA SOCIEDADE BRASILEIRA DE ZOOTECNIA, 34., 1997, Juiz de Fora. Anais... Juiz de Fora: SBZ, 1997. (CD-ROM).

MAGNABOSCO, C.D.U.; DIAS, D.O.; FARIA, C.U. et al. Estudo genético quantitativo do perímetro escrotal em análise multicaracter utilizando dados de campo de bovinos da raça Nelore. In: REUNIÃO ANUAL DA SOCIEDADE BRASILEIRA DE ZOOTECNIA, 40., 2003, Santa Maria. Anais... Santa Maria: SBZ, 2003. (CD-ROM).

MISZTAL, I. [2007]. BLUPF90 family of programs. Available at: <http://nce.ads.uga.deu/ ignacy/newprograms.html $>$. Accessed on: July 21, 2009.

MOTA, M.D.S.; PRADO, R.S.A.; FERREIRA, D.F.M.G. Estimativa de parâmetros genéticos para o deslocamento em cavalos da raça Mangalarga. Archivos de Zootecnia, v.55, n.210, p.207-210, 2006.

MOTA, M.D.S.; OLIVEIRA, H.N.; PUOLI FILHO, J.N.P. et al. Avaliação do crescimento em potros da raça Quarto de milha. Revista Electrónica de Veterinaria, v.11, n.1, p.1-10, 2010

PRADO, R.S.A.; MOTA, M.D.S. Genetic parameters for biometric traits in Mangalarga horses. Revista Electrónica de Veterinaria, v.9, n.12, p.1-15, 2008.

RAFTERY, A.L.; LEWIS, S. Comment: one long run with diagnostics: implementation strategies for Markov chain Monte Carlo. Statistical Science, v.7, n.4, p.493-497, 1992.

SANTOS, L.M. Morfologia e genética do cavalo campolina. 2006. 49f. Dissertação (Mestrado em Genética) - Instituto de Ciências Biológicas/Universidade Federal de Minas Gerais, Belo Horizonte.

SANTOS, S.A.; SOUZA, G.S.; ABREU, U.G.P. et al. Monitoramento do desenvolvimento de cavalos pantaneiros por meio de curvas 
de crescimento. Archivos de Zootecnia, v.56, sup. 1, p.647-654, 2007.

THOMPSON, K.N.; SMITH, B.P. Skeletal growth patterns of Thoroughbred horses. Journal of Equine Veterinary Science, v.14, p.148-151, 1994.

VAN KAAM, J.B.C.H.M. "GIBANAL" - Analyzing program for Markov Chain Monte Carlo Sequences (Version 2.10). Wageningen: Department of Animal Sciences, Wageningen Agricultural University, 1998. 4p. (Manual).
WINTER, E.M.W. Estimação de parâmetros genéticos de características de desempenho, carcaça e composição corporal de codornas para corte (Coturnix sp.). 2005. 91f. Dissertação (Mestrado em Genética) - Universidade federal do Paraná, Curitiba. ZAMBORLINI, L.C.; BERGMANN, J.A.G.; PEREIRA, C.S. et al. Estudo genético quantitativo das medidas lineares da raça Mangalarga Marchador. I. Estimativas dos fatores de ambiente e parâmetros genéticos. Revista Brasileira de Ciências Veterinárias, v.3, n.2, p.33-37, 1996 